\title{
Patterns of induced variation in the morphology, hyaluronic acid secretion, and lysosomal enzyme activity of cultured human synovial cells
}

\author{
J. R. E. FRASER, B. J. CLARRIS, AND ELSMAREE BAXTER.
}

From the University of Melbourne Department of Medicine, Royal Melbourne Hospital, Victoria, Australia

SUMMARY In contrast with newly isolated cells or early primary cultures, synovial cell lines in standardised growth conditions assume a rather uniform fibroblast-like appearance. However, 2 distinct variations in the cytological pattern can be induced at this stage. The first is characterised primarily by increased numbers of small phase-dense organelles that show the distinctive fluorescence of lysosomes after supravital staining, and are interspersed with vacuoles. The associated functional changes include increased enzyme activity and decreased net synthesis of hyaluronic acid. This variation can be induced by exposure to indigestible neutral sugars, adenosine, or its $5^{\prime}$ nucleotides. The second variation consists of a striking reorganisation of cytoplasm by condensation into dense ridges or a dendritic network of processes. It is accompanied by increased hyaluronic acid secretion and is induced by agents that enhance intracellular activity of cyclic adenosine monophosphate, such as dibutyryl cyclic adenosine monophosphate and cholera enterotoxin. It appears possible to direct differentiation in synovial cell lines to correspond at least in part with the presumed functions of the different cell types in the parent tissue. The 2 patterns may be useful markers to correlate with other aspects of synovial cell function in vitro.

Cultured synovial cell lines offer the experimental advantage of large numbers, continued availability during their diploid life span, and precise replication of test cultures, but they usually present a fibroblastlike appearance which is a serious reservation in relating their behaviour to synovial tissue in vivo.

Immediately after dispersal by trypsin the distinct cell types of the synovial intima are still recognisable (Williamson et al., 1966; Kinsella et al., 1970): type A with macrophage-like features; type $B$ with abundant endoplasmic reticulum suggesting synthetic functions; and type $\mathrm{C}$ with well developed elements of both kinds. In the transition to cell lines the macrophage-like cells of primary cultures become rare after the first few passages. Synovial cell lines secrete glycosaminoglycans and collagen (Castor and Muirden, 1964) like other fibroblasts. Yet they retain a high capacity for endocytosis of particulate and soluble materials (Clarris and Fraser, 1968; Muirden et al., 1967; Werb and Reynolds, 1974), and their ultrastructure resembles

Accepted for publication 31 July 1978

Correspondence to Dr J. R. E. Fraser, University of Melbourne Department of Medicine, Royal Melbourne Hospital Post Office, Victoria 3050, Australia. that of the type $\mathrm{C}$ intima cell (Castor and Muirden, 1964), which suggests that their functional activities may be turned in the several directions implicit in the ultrastructure of the intima.

Their microscopic appearance can change with variations in cultural conditions and with specific treatments, but the changes have not been systematically described or correlated with cell function. In controlled experiments 2 distinct patterns of morphological differentiation may be discerned. A previous report described structural changes simulating the type A cell, which followed the presumptive endocytosis of indigestible neutral sugars (Le Marshall et al., 1977). During other studies a quite different appearance was observed on exposure to the cyclic nucleotide, dibutyryl cyclic adenosine monophosphate. This paper describes these 2 patterns of response and several means for inducing them, together with associated changes in secretory and lysosomal enzyme activity.

Materials and methods

CELL CULTURE

The establishment of synovial cell lines, replication 
of experimental cultures, and estimation of cell numbers by electronic cell counter have been described elsewhere (Fraser and McCall, 1965; Clarris and Fraser, 1967). Stock cultures were maintained in Eagle's basal medium (EBM) supplemented by heat-inactivated serum, $10 \%$ fetal calf (FCS) and $10 \%$ human (HS). Experimental cultures were plated out at approximately 8000 cells $/ \mathrm{cm}^{2}$ in EBM with $20 \%$ FCS for $24 \mathrm{~h}$, randomised for treatments, and observed for 3-day intervals in EBM with $20 \%$ HS and the appropriate test substances. Eighteen different cell lines were studied from the 3rd to the 18th passage between 18 and 143 days after primary isolation. The human embryonic fibroblast line, MRC5 (Jacobs et al., 1970) was kindly provided by Mrs Jean Ferguson Stanley, Commonwealth Serum Laboratories, Melbourne.

\section{SECRETORY ACTIVITY}

Sodium $\left({ }^{3} \mathrm{H}\right)$ acetate (TRK12, Radiochemical Centre, Amersham), $25 \mu \mathrm{Ci} / \mathrm{ml}$ of culture medium, was used as substrate for hyaluronic acid synthesis. Culture media were centrifuged in a $\mathrm{CsCl}$ gradient developed in a Beckham 50 Ti rotor at 40000 r.p.m. for $60 \mathrm{~h}$ (initial density 1.51; final 1.63-1.42). Samples were fractionated by downward displacement, and exhaustively dialysed before counting ${ }^{3} \mathrm{H}$ activity in a Packard Tricarb scintillation counter. Tritiated hyaluronic acid was completely recovered in the first $4 \mathrm{ml}$, and further identified by separation in its characteristic zone on ultracentrifugation in $\mathrm{CsCl}$-guanidinium $\mathrm{Cl}$ (initial density 1.46), and by degradation with bacterial hyaluronidase (NV Organon; $10900 \mathrm{IU} / \mathrm{mg}$ ). ${ }^{3} \mathrm{H}$ labelled protein was recovered in the last $4 \mathrm{ml}$ of each $11 \mathrm{ml}$ sample. Individual proteins were not further characterised in this study.

\section{LYSOSOMAL ENZYME ACTIVITY}

$\mathrm{N}$-acetyl- $\beta$-D-glucosaminidase was measured in culture medium and cell extracts by the methods used earlier (Le Marshall et al., 1977) except that centrifugation was standardised at $1400 \mathrm{~g}$ and the ultrasonication step was eliminated. For accuracy, stability, and sensitivity this has been found to be the most suitable lysosomal enzyme for measurement in these cells and media.

\section{EXPERIMENTAL TREATMENTS}

Dibutyryl cyclic $3^{\prime}, 5^{\prime}$,adenosine monophosphate (dbcAMP), cyclic $3^{\prime}, 5^{\prime}$, adenosine monophosphate (cAMP), adenosine, adenosine 5 'triphosphate (ATP) (Calbiochem), n-butyric acid (BDH), and theophylline (BDH) were incorporated in the test media from freshly prepared and filtered stock solutions in EBM. Cholera enterotoxin (CET; Schwarz-Mann) was dissolved in Hanks's balanced salt solutior (HBSS) and applied for 45-90 min to cultures rinsed: free of culture medium, then removed and replaces with test medium. When CET was compared witho other agents, the other cultures were similarlyo treated with HBSS alone.

\section{MICROSCOPY}

Negative medium phase contrast was used as described previously. Since synovial cells grow in an overlapping reticular pattern long before confluence $\vec{w}$ quantitation of morphological change by differentia? count is difficult. Pairs of control and treated culture were therefore assessed in random order unknowio to the examiner and ranked in respect of the maind features of fine structure. Results were assessed by 80 1-tailed binomial test, a precaution only necessary to detect early or slight changes.

Table 1 Morphological patterns in synovial cell lines

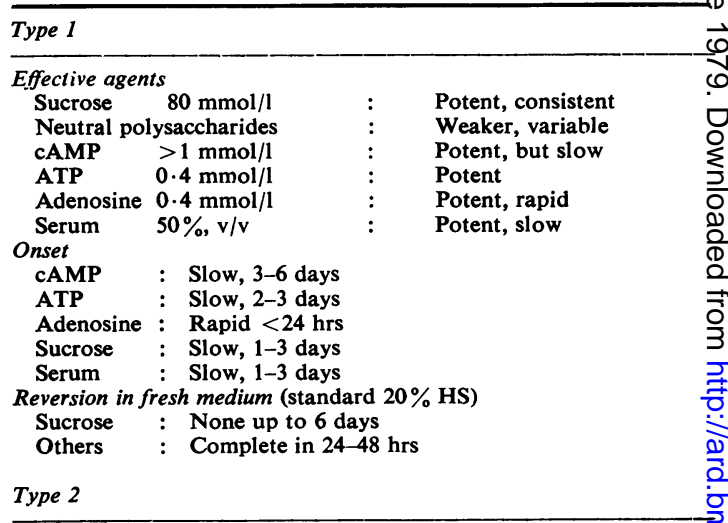

Effective agents

Cholera enterotoxin, $10^{-9}-10^{-7} \mathrm{~mol} / 1$ : Very potent, most rapid dbcAMP $\quad 0.4 \mathrm{mmol} / 1 \quad$ : $\quad$ Potent, slower

cAMP $5 \mathrm{mmol} / 1$ : Weak, assoc. type 1 response

$\left.\begin{array}{l}\text { Theophylline, } \\ \text { isobutyl methyl }\end{array}\right\} 1 \mathrm{mmol} / 1$ : Weak, variable, may xanthine potentiate others

Hormones

(Parathormone, calcitonin) : Weak, transient

Serum, $<10 \%, v / v$

Carrageenin

n-Butyric acid

$0.4-1.0 \mathrm{mmol} / 1$

Onset

Cholera enterotoxin dbcAMP

Other agents

Further Development

Cholera enterotoxin dbcAMP

Others

Reversion in fresh medium Cholera enterotoxin dbcAMP

Reversion by treatment $4^{\circ} \mathrm{C}$ for $5 \mathrm{~h}$

Colchicine $10^{-6} \mathrm{~mol} / 1$

Vinblastine $10^{-5} \mathrm{~mol} / 1$
Weak to moderate

Potent

No effect

4-5 h

18-48 h

Variable, $>24 \mathrm{~h}$

Rapid

Continues to 6 days

Variable

None in 6 days

$>3 \mathrm{~h}<18 \mathrm{~h}$

None

Partial only, incomplete 24 Rapid, nearly complete $5 \mathrm{~h}$ 
SUPRAVITAL STAINING

Cultures were stained in acridine orange (G. T. Gurr), $10 \mu \mathrm{g} / \mathrm{ml}$ for $20 \mathrm{~min}$ at $37^{\circ} \mathrm{C}$, washed and examined in deep violet light. Black-and-white prints were prepared from colour transparencies by exposure through a Kodak Wratten No. 25 filter on to Kodak Panatomic X film.

\section{EXPERIMENTAL DESIGN}

Each treatment was assessed by comparison with control cultures alone and by simultaneous study with other treatments.

\section{Results}

\section{MOR PHOLOGY}

The cytological changes fall into 2 distinct groups. A few cells showing either pattern may be found in any culture, but in most experimental treatments one or the other usually dominates any perceptible difference from the matched controls. The 2 patterns of response have therefore been designated as type 1 and type 2.

Type 1 response (Figs. 1 and 2). The range of effective stimuli so far established is shown in Table 1 with other aspects of the response. Apart from the degree of vacuolation the changes are essentially the same as those induced by sucrose (Le Marshall et al., 1977). Similar effects also follow an excessive fall in $\mathrm{pH}$, but it is not established whether $\mathrm{pH}$ as such or other metabolic changes are responsible.

Type 2 response. This highly distinctive change was observed when dbcAMP was used to stimulate hyaluronic acid synthesis, and seemed likely to reflect increased intracellular cAMP activity. A standard level of $0.4 \mathrm{mmol} / \mathrm{l}$ was adopted for comparisons, since this is the point at which hyaluronic acid secretion consistently begins to rise (Castor et al., 1974). The changes fall into two categories.

(a) The cytoplasm first condenses into ridges (Fig. 3) and then into dense, sharply defined, and rather straight folds, with angular intersections
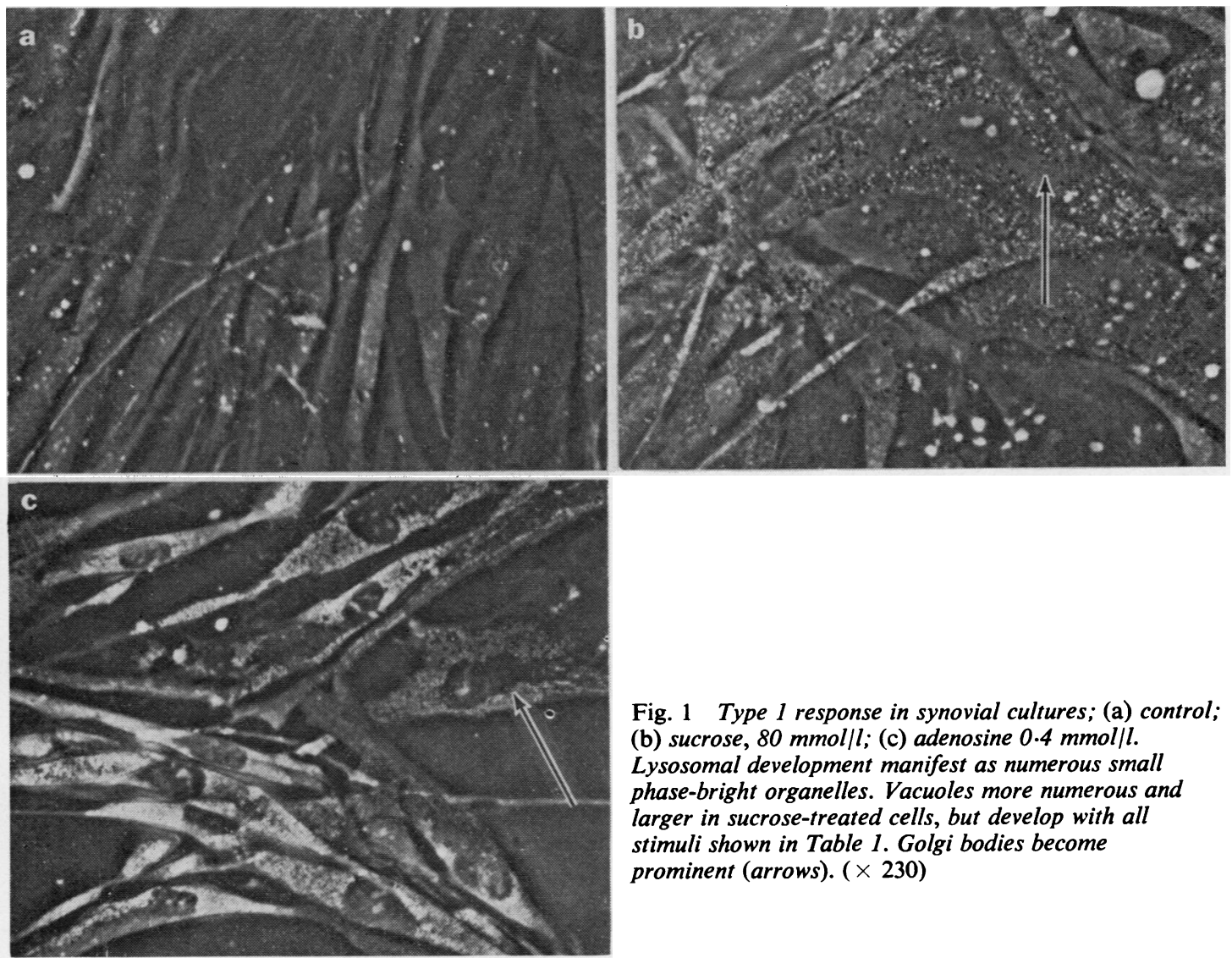

Fig. 1 Type 1 response in synovial cultures; (a) control; (b) sucrose, $80 \mathrm{mmol} / \mathrm{l}$; (c) adenosine $0.4 \mathrm{mmol} / \mathrm{l}$. Lysosomal development manifest as numerous small phase-bright organelles. Vacuoles more numerous and larger in sucrose-treated cells, but develop with all stimuli shown in Table 1. Golgi bodies become prominent (arrows). ( $\times 230)$ 

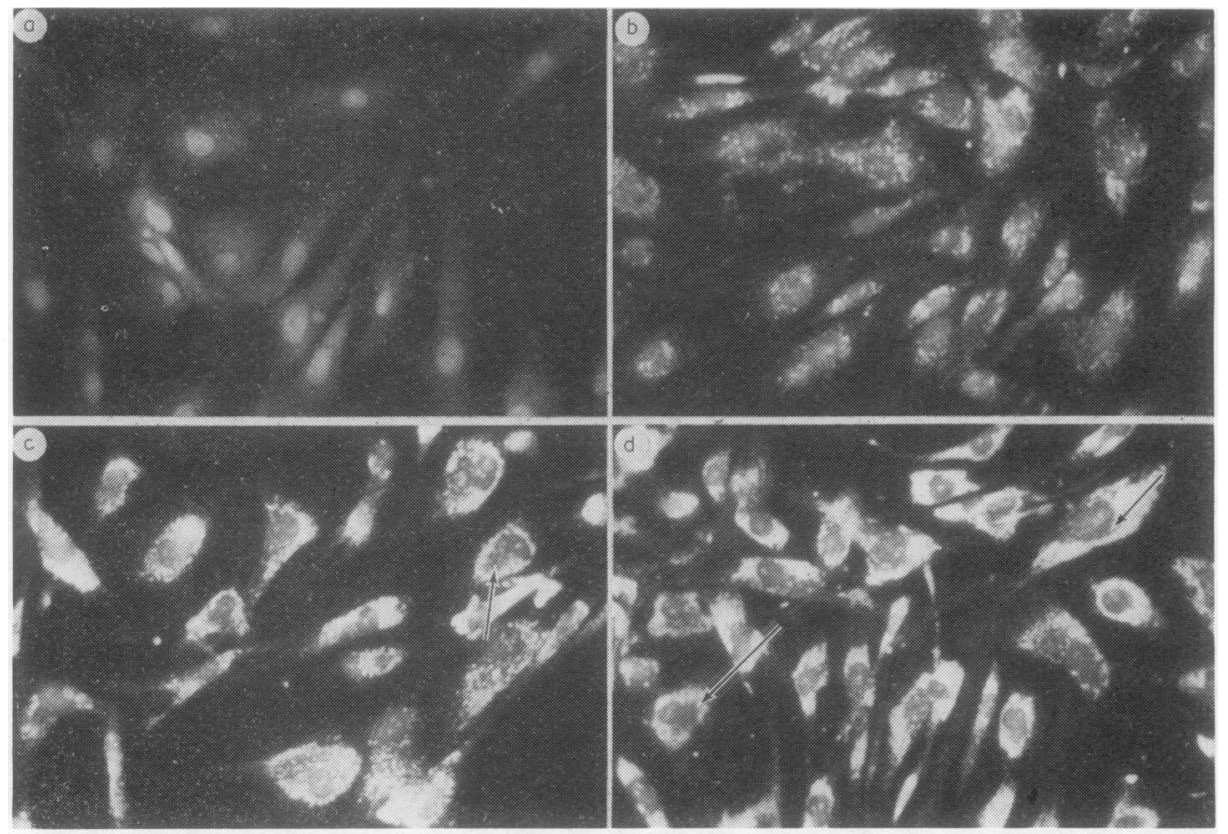

Fig. 2 Synovial cultures after 3 days in (a) control medium; (b) dbcAMP, $0.4 \mathrm{mmol} / \mathrm{l}$; (c) ATP, $0.4 \mathrm{mmol} / \mathrm{l}$; (d) adenosine, $0.4 \mathrm{mmol} / \mathrm{l}$. Acridine orange supravital staining. Specific red fluorescence of lysosomes shown as bright granules in cytoplasm. Lysosomes scarce in control cultures, more prominent in dbcAMP, and very numerous in ATP and adenosine. Arrows indicate presumed Golgi bodies. Type 2 changes induced by dbcAMP cannot be detected with this method. $(\times 245)$
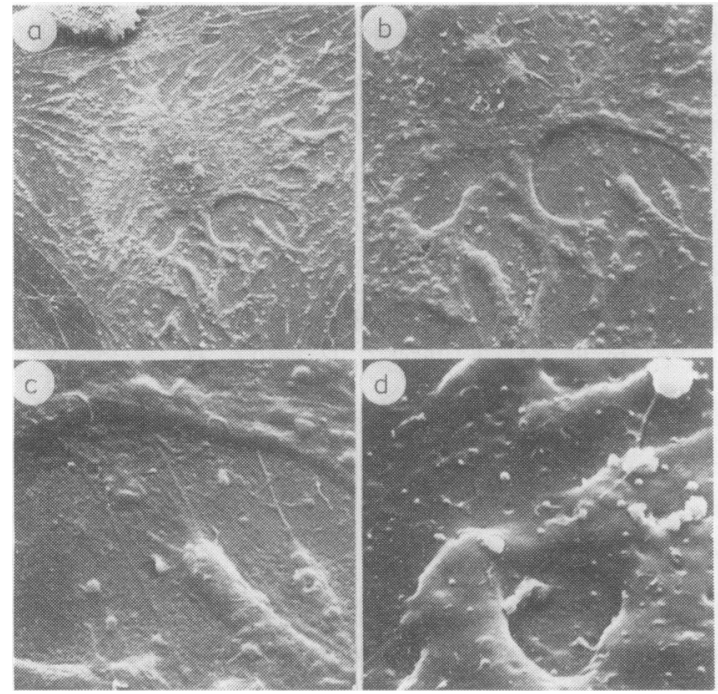

Fig. 3 Early development of cytoplasmic ridging in type 2 (a) response. Scanning electron microscopy of cells treated with dbcAMP. Ridging appears to develop about fine linear structures. Intervening cytoplasm very thin, but still largely intact. $(a, \times 650 ; b \times 1150$; $c, \times 2750 ; d, \times 2750$ ). and flattening of the intervening cytoplasm (Fig. 4을 upper panels). Depending on the intensity of the reaction, this change may affect more than two-thirdș. of the cells. It is quite distinct from the effect of similar stimuli on human embryonic fibroblasts̄ (MCR5 line), which show increased cytoplasmie spreading with peripheral fimbriation but no discernible reorganisation within.

(b) In the most intense reactions the long pro cesses of some cells become opaque and irregular? with small beaded excrescences. In other cells, similap processes develop by fenestration of the thinnee. cytoplasm in the ridged cells and condensation at the bases of the processes to give a dendritic or astrocyte: like picture (Fig. 4, lower panels). In the type s0 response phase-dense organelles are usually obscuredç but with supravital staining an increase in numbere was occasionally detected (Fig. 2b).

The specificity of the type 2 response was examined by using several dissimilar substances known to increase the activity of endogenous cAMP (Table 1) Cholera enterotoxin (CET), which causes persisten? activation of adenyl cyclase (O'Keefe and Cuatre cases, 1974), is the most rapid and potent stimulan so far studied. The phosphodiesterase inhibitors? isobutyl methyl xanthine and theophylline 
produced weak and variable type 2 changes and were inconsistent in potentiating other agents. The hormones calcitonin and parathyroid hormone, both stimulants of hyaluronic acid secretion (Baxter et al., 1968; Severson et al., 1973), produced weak type 2 changes which reverted after $24 \mathrm{~h}$ despite continued exposure. Exogenous cAMP alone induced a type 1 response between 1 and $5 \mathrm{mmol} / \mathrm{l}$, with a superadded weak type 2 change only at $5 \mathrm{mmol} / \mathrm{l}$. Other aspects of the type 2 morphological response are shown in Table 1.

\section{F UNCTIONAL CHANGES}

Lysosomal enzyme activity ( $\mathrm{N}$-acetyl- $\beta$-D-glucosaminidase). In type 1 responses changes in enzyme activity were usually consistent with the morphological reactions. Cyclic AMP at $1 \mathrm{mmol} / \mathrm{l}$ caused modest increases in enzyme activity. Adenosine, like sucrose (Le Marshall et al., 1977), is a potent stimulant of enzyme activity (Table 2), and the only agent so far found to enhance release of active lysosomal enzyme without other evidence of cell damage.

Modest rises in enzyme activity (about 15\%) occurred with dbcAMP ( 2 of 7 studies) and CET (2 of 6), mainly with prolonged treatment (144 h) or higher concentrations (Fig. 5). Exposure to dbcAMP after stimulation of enzyme activity by sucrose had no further effect on intracellular enzyme levels or release.

Hyaluronic acid secretion. (Table 3). Cyclic AMP, adenosine, and ATP all caused significant depression of hyaluronic acid synthesis as earlier found with sucrose. The effect of cAMP was nullified by theo-
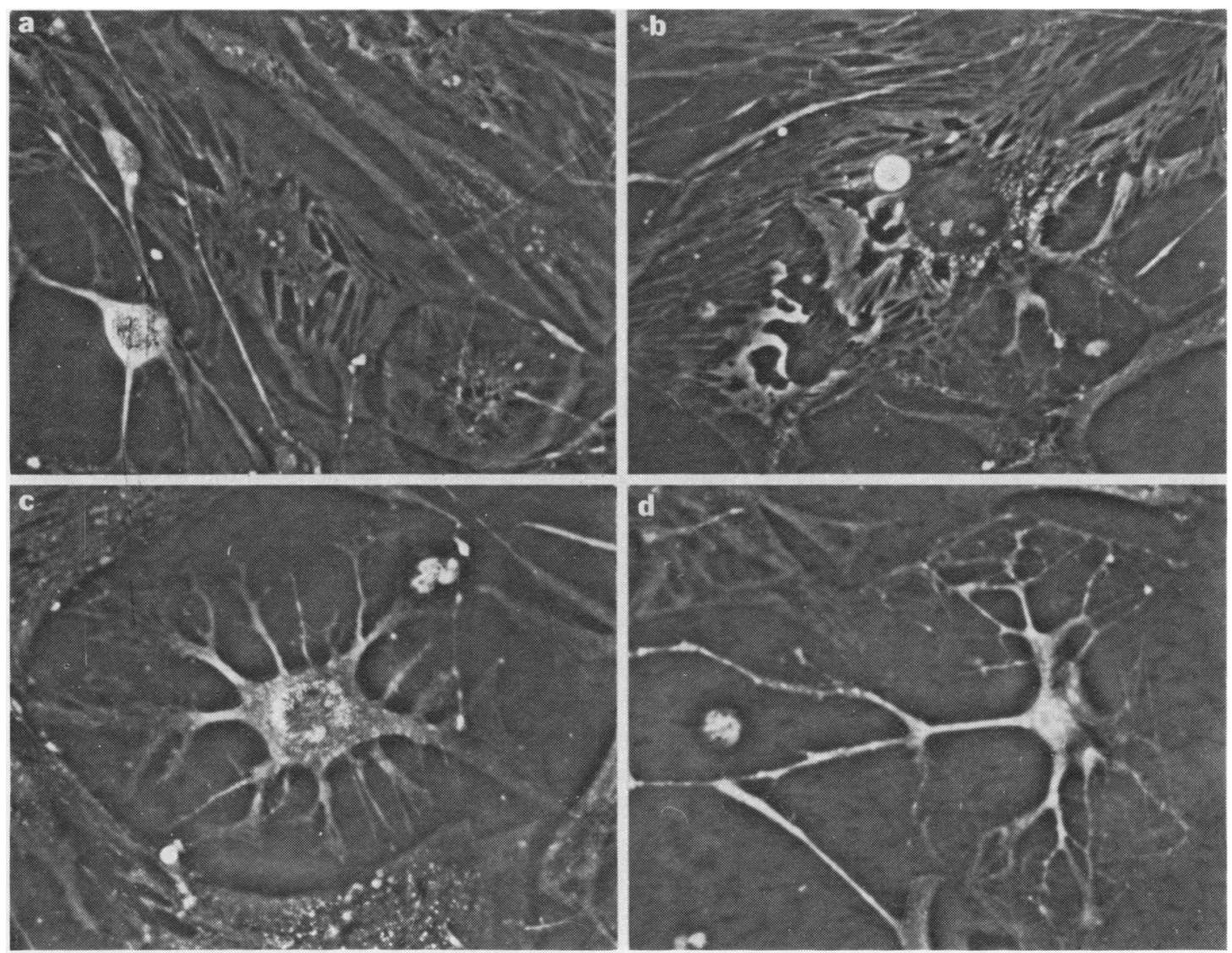

Fig. 4 Type 2 response in synovial cultures. Cultures treated with cholera enterotoxin, $10^{-7}$ mol $/ l$ for 45 min, and maintained in standard medium for 3 days. Large cells selected for clarity. Note sequence from dense ridging and thinning in widely spread cytoplasm (2a response, Figs. $4 a, 4 b)$ to retraction and condensation as opaque irregular dendritic processes ( $2 b$ response, Figs. $4 c, 4 d)$. These still appear to encompass the original cytoplasmic territory. (Both polar and spread forms often extend more than $500 \mu \mathrm{m}$ in primary cultures or cell lines). $(\times 230)$. 
Table 2 Lysosomal enzyme activity; type 1 response

\begin{tabular}{|c|c|c|c|c|}
\hline \multirow{2}{*}{$\begin{array}{l}\text { Treatment } \\
\text { ( } 3 \text { days) }\end{array}$} & \multirow{2}{*}{$\begin{array}{l}\text { Morvho- } \\
\text { logical } \\
\text { change }\end{array}$} & \multicolumn{3}{|c|}{$N$-acetyl- $\beta$-D-glucosaminidase ${ }^{*}$} \\
\hline & & $\begin{array}{l}\text { Intra- } \\
\text { cellular }\end{array}$ & $\begin{array}{l}\text { Extra- } \\
\text { cellular** }\end{array}$ & Total \\
\hline $\begin{array}{l}\text { A } \\
\text { Control } \\
\text { Adenosine } \\
\quad 0.4 \mathrm{mmol} / 1\end{array}$ & $\bar{t}+$ & $\begin{array}{l}120 \pm 3 \cdot 3 \\
167 \pm 15 \cdot 0 \\
N S\end{array}$ & $\begin{array}{l}104 \pm 7 \cdot 9 \\
292 \pm 2 \cdot 8 \dagger \dagger\end{array}$ & $\begin{array}{l}224 \pm 7 \cdot 1 \\
459 \pm 12 \cdot 7 \dagger \dagger\end{array}$ \\
\hline $\begin{array}{l}\text { B } \\
\text { Control } \\
\text { Adenosine } \\
\quad 0.5 \mathrm{mmol} / 1\end{array}$ & $\overline{t+}+$ & $\begin{array}{c}55 \pm 4 \cdot 4 \\
103 \pm 5 \cdot 6 \dagger \dagger\end{array}$ & $\begin{array}{l}123 \pm 1 \cdot 2 \\
238 \pm 4 \cdot 6 \dagger \dagger\end{array}$ & $\begin{array}{l}179 \pm 5 \cdot 6 \\
341 \pm 9 \cdot 6 \dagger \dagger\end{array}$ \\
\hline $\begin{array}{l}\text { C } \\
\text { Control } \\
\text { Adenosine } \\
\quad 0.5 \mathrm{mmol} / 1\end{array}$ & $\bar{t}++$ & $\begin{array}{l}61 \pm 3 \cdot 7 \\
88 \pm 7 \cdot 9 \dagger \dagger\end{array}$ & $\begin{array}{c}81 \pm 0 \cdot 8 \\
135 \pm 9 \cdot 3 \dagger \dagger\end{array}$ & $\begin{array}{l}142 \pm 4 \cdot 5 \\
223 \pm 7 \cdot 0 \dagger \dagger\end{array}$ \\
\hline $\begin{array}{l}\text { D } \\
\text { Control } \\
\text { Adenosine } \\
\quad 0.5 \mathrm{mmol} / 1\end{array}$ & $\bar{t}+$ & $\begin{array}{l}65 \pm 3 \cdot 5 \\
95 \pm 2 \cdot 3 \dagger \dagger\end{array}$ & $\begin{array}{l}117 \pm 4 \cdot 6 \\
134 \pm 2 \cdot 9 \dagger\end{array}$ & $\begin{array}{l}182 \pm 7 \cdot 0 \\
229 \pm 4 \cdot 7 \dagger \dagger\end{array}$ \\
\hline $\begin{array}{l}\text { Sucrose } \\
\quad 80 \mathrm{mmol} / \mathrm{l}\end{array}$ & +++ & $129 \pm 7 \cdot 7 \dagger \dagger$ & $95 \pm 5 \cdot 1 \dagger$ & $224 \pm 3 \cdot 3 \dagger \dagger$ \\
\hline
\end{tabular}

* $\mu$ g p-nitrophenol released $\mathrm{h} / 10^{6}$ cells, mean \pm SEM. ** Lactic dehydrogenase not increased above level in original medium. For difference from control: $\mathrm{NS}=$ not significant; $\dagger=\mathrm{p}<0.05$; $\dagger+=\mathbf{P}<0.01$.

Table 3 Secretory responses

\begin{tabular}{|c|c|c|c|c|}
\hline \multirow[t]{2}{*}{$\begin{array}{l}\text { Treatment } \\
\text { (3 days) }\end{array}$} & \multicolumn{2}{|c|}{$\begin{array}{l}\text { Morphological } \\
\text { changes }\end{array}$} & \multicolumn{2}{|c|}{$\begin{array}{l}\text { Secretions, }\left({ }^{3} H\right) \text { acetate } \\
d p m / \text { cell Mean } \pm S E M\end{array}$} \\
\hline & Type 1 & Type 2 & $\begin{array}{l}\text { (a) hyalu- } \\
\text { ronic }\end{array}$ & (b) protein \\
\hline \multicolumn{5}{|l|}{ A } \\
\hline Control & - & - & $74 \pm 1 \cdot 8$ & $26 \pm 2 \cdot 3$ \\
\hline $\begin{array}{l}\text { dbcAMP } \\
0.4 \mathrm{mmol} / 1\end{array}$ & - & +++ & $68 \pm 3 \cdot 8$ & $20 \pm 1 \cdot 1$ \\
\hline $\begin{array}{l}\text { CAMP } \\
1.0 \mathrm{mmol} / 1\end{array}$ & - & - & $29 \pm 0 \cdot 6^{* * *}$ & $27 \pm 0 \cdot 3$ \\
\hline $\begin{array}{l}\text { CET } \\
10^{-7} \mathrm{~mol} / 1\end{array}$ & - & $+++t$ & $124 \pm 1 \cdot 9^{* * *}$ & $22 \pm 0 \cdot 2$ \\
\hline \multicolumn{5}{|l|}{ B } \\
\hline Control & - & - & $63 \pm 1 \cdot 8$ & $49 \pm 5 \cdot 5$ \\
\hline $\begin{array}{l}\text { dbcAMP } \\
0.4 \mathrm{mmol} / 1\end{array}$ & - & ++ & $73 \pm 3 \cdot 5$ & $43+1 \cdot 8$ \\
\hline $\begin{array}{l}\text { ATP } \\
0.2 \mathrm{mmol} / 1\end{array}$ & + & - & $53 \pm 0 \cdot 3^{* *}$ & $49 \pm 1 \cdot 2$ \\
\hline $\begin{array}{l}\text { ATP } \\
\quad 0.4 \mathrm{mmol} / 1\end{array}$ & + & - & $38 \pm 1 \cdot 2^{* * *}$ & $42 \pm 2 \cdot 5$ \\
\hline $\begin{array}{l}\text { Adenosine } \\
0.4 \mathrm{mmol} / \mathrm{l}\end{array}$ & +++ & - & $42 \pm 0 \cdot 6^{* * *}$ & $44 \pm 1 \cdot 1$ \\
\hline \multicolumn{5}{|l|}{ C } \\
\hline Control & - & - & $84 \pm 3 \cdot 7$ & $26 \pm 0.4$ \\
\hline $\begin{array}{l}\text { Adenosine } \\
0.4 \mathrm{mmol} / 1\end{array}$ & +++ & - & $66 \pm 2 \cdot 5^{*}$ & $23 \pm 0 \cdot 7$ \\
\hline $\begin{array}{l}\text { cAMP } \\
2 \mathrm{mmol} / 1\end{array}$ & - & - & $52 \pm 1 \cdot 0^{* * *}$ & $25 \pm 1 \cdot 6$ \\
\hline $\begin{array}{l}\text { cAMP, } 2 \mathrm{mmol} / 1 \\
+ \text { theophylline } \\
1 \mathrm{mmol} / 1\end{array}$ & - & + & $88 \pm 1 \cdot 2$ & $22 \pm 0 \cdot 2$ \\
\hline $\begin{array}{l}\text { dbcAMP } \\
\quad 0.4 \mathrm{mmol} / 1\end{array}$ & - & +++ & $119 \pm 0 \cdot 9^{* * *}$ & $23 \pm 2 \cdot 2$ \\
\hline $\begin{array}{l}\mathrm{CET} \\
10^{-7} \mathrm{~mol} / 1\end{array}$ & - & +++ & $158 \pm 2 \cdot 9^{* * *}$ & $25 \pm 0 \cdot 7$ \\
\hline
\end{tabular}

For difference from control : $*=\mathrm{P}<0.05 ; * *=\mathrm{P}<0 \quad 02 ; * * *=\mathrm{P}<0.01$

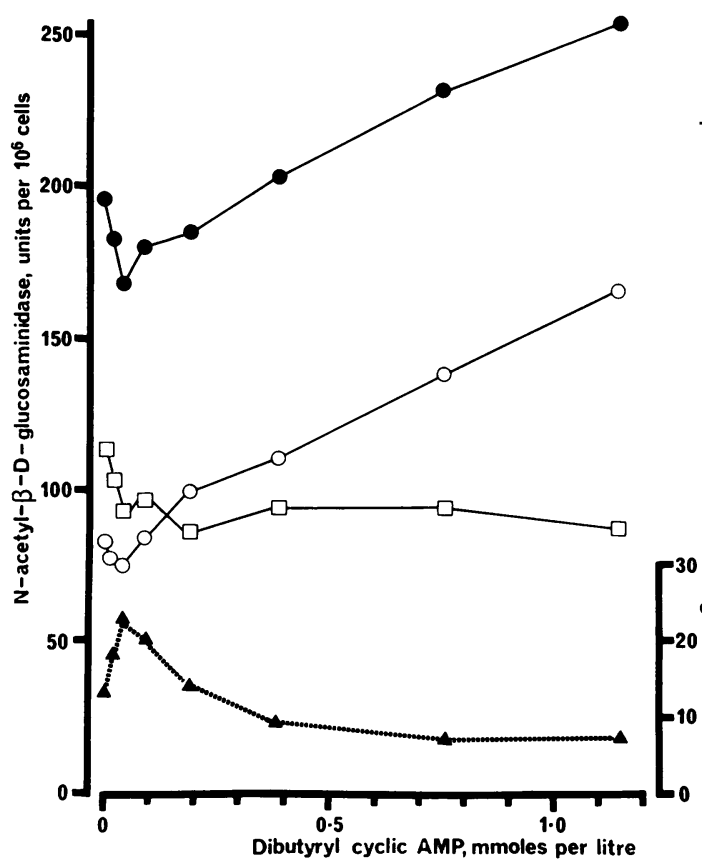

Fig. 5 Cell growth and lysosomal enzyme activity $(N$-acetyl- $\beta$ - $D$-glucosaminidase) in increasing concentrations of dbcAMP. Enzyme activity ( $\mu g$ p-nitrophenol released $/ h) ; \square=$ Extracellular. $\mathrm{O}=$ Intracellular. $\bullet=$ Total. Cell growth; $\Delta=$ mean daily percentage increase in cell numbers

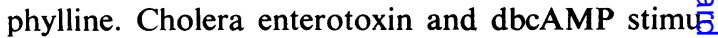
lated hyaluronic acid synthesis. In 14 additionat studies with dbcAMP, $0.4 \mathrm{mmol} / \mathrm{l}$, the increase $\mathrm{i}$. hyaluronic acid secretion ranged from 0 to $300 \%$ (mean 65\%; median $45 \%$ ), consistent with the varied dose response curves reported by Castor et al. (1974?

Protein secretion. No marked change was observed This does not preclude changes in proteins with low content of acetylamino sugars.

Growth rates. Most of the agents caused a relative slowing of cell multiplication with either type 1 on type 2 response. Although some of the presento findings (e.g., Fig. 5) and those of others indicate a inverse relationship between growth rate and levels of endogenous cAMP, the observed changes in morphology, hyaluronic acid secretion, and lyso somal enzyme activity were all found at times to bब independent of cell growth rates. For example, som of the most extreme type 2 changes developed in CET-stimulated cultures with mean cell doublin 8 times equal to those of matched controls and as short as $25 \mathrm{~h}$. 


\section{Discussion}

The elements of the type 1 response are common features of enhanced activity in the phagolysosomal complex, which is already more prominent in synovial than in other fibroblast lines without specific treatment. Complete reversion to the macrophage-like cells of primary culture with their typically rounded appearance, dense granular structure, and very firm adhesion has not yet been reproduced. More intense stimulation, direct measurement of phagocytosis, and markers such as $\mathrm{Fc}$ and $\mathrm{C} 3$ receptors may give a better idea of the potential for such differentiation.

The type 2 response has not been described in synovial cells before, although enhanced activity of intracellular cAMP modifies the cytoplasm in most kinds of cells. The type $2(a)$ response is similar to the spreading response of other fibroblasts (Johnston and Pastan, 1972), with the added characteristic of intense ridge formation. The type $2(b)$ response resembles the internal retraction of cytoplasm seen in bone cells (Miller et al., 1976) and iris epithelial cells (Ortiz et al., 1973), which also adopt a stellate or filigree pattern encompassing the original cell territory. In other cell types there is an aggregation of microfibrils around the microtubules after endogenous cAMP activation (Willingham and Pastan, 1975). The response of activated synovial cells to colchicine and vinblastine suggests a similar ultrastructural rearrangement.

With the exception of carrageenin (Clarris et al., in press) and serum (Fraser and Clarris, 1978), which have complex actions, the 2 morphological patterns appear to be associated with specific functional changes. In the type 1 response, hyaluronic acid synthesis is depressed and intracellular lysosomal enzyme activity increases, as noted earlier with sucrose activation (Le Marshall et al., 1977). These changes sometimes occurred without discernible morphological differences, but the latter can be difficult to detect when the control cultures show a moderate complement of organelles. Work in progress has shown no evidence of extracellular degradation of hyaluronic acid, but resorption and intracellular degradation have not been excluded. The striking difference in the effects of sucrose and adenosine upon extracellular enzyme may depend on the form in which it is released (Kaplan et al., 1977; Neufeld et al., 1977). In the type 2 response increased hyaluronic acid synthesis is the only consistent association so far defined, but concomitant changes in collagen synthesis (Castor et al., 1971a; 1971b) have not been excluded. The morphological change, which is easily detected, can occur below the threshold for increased hyaluronic acid synthesis. Conversely, structural changes may not develop with short-lived functional responses such as those induced by hormones.

Exogenous cAMP is commonly less effective than dbcAMP, which has been attributed to poorer penetration (Henion et al., 1967). In this study it was not simply less potent, but below $5 \mathrm{mmol} / \mathrm{l}$ any morphological effects were quite different, and hyaluronic acid synthesis was depressed. In some cell types it is rapidly transformed after penetration to ADP and ATP (Hsie et al., 1975; Granner et al., 1975). In macrophages, adenosine and its 5'nucleotides greatly stimulate pinocytosis (Cohn and Parks, 1977), which in turn can activate the lysosomal complex. This seemed a likely explanation for the effects of cAMP and prompted the use of ATP and adenosine. The lysosomal activation seen with dbcAMP and CET may be similarly linked with a sustained elevation of intracellular cAMP. However, it was not sufficient to depress hyaluronic acid synthesis and may be irrelevant in normal circumstances.

The 2 patterns may be useful markers of other synovial cell functions in vitro. For example, the distinctive cells of the type $2(b)$ response seem identical with the 'dendritic' cells observed by Werb et al. (1977) to arise spontaneously in primary rheumatoid cultures. Large amounts of collagenase were produced when those cells were most numerous. The 'dendritic' cells became extremely scarce after subculture. Collagenase activity also declines after subculture of rheumatoid cells (Dayer et al., 1976) and is difficult to detect in nonrheumatoid human synovial cell lines (Werb and Burleigh, 1974).

It may therefore be possible to re-establish collagenase secretion in these circumstances by using the agents that have been found to induce the 'dendritic' kind of cell.

We are grateful to Professor C. W. Castor for advice on the use of cyclic nucleotides; to Miss Nan Carroll for electron microscopy; to Mrs L. Malcolm and Mr M. Holmes for technical assistance; to $\mathrm{Mr}$ Arthur Wigley for special photographic services; and to N. V. Organon for the gift of bacterial hyaluronidase. This work was supported by the National Health and Medical Research Council of Australia.

\section{References}

Baxter, E., Fraser, J. R. E., Harris, G. S., Martin, T. J., and Melick, R. A. (1968). Stimulation of glycosaminoglycan synthesis by thyrocalcitonin preparations. Medical Journal of Australia, 1, 216-217.

Castor, C. W., Dorstewitz, E. L., Rowe, K., and Ritchie, J. C. (1971a). Abnormalities of connective tissue cells cultured from patients with rheumatoid arthritis. II. Defective regulation of hyaluronate and collagen formation. Journal of Laboratory and Clinical Medicine, 77, 65-75.

Castor, C. W., Dorstewitz, E. L., Smith, S. F., and Ritchie, J. C. (1971b). Connective tissue activation. I. The nature, 
specificity, measurement and distribution of connective tissue activating peptide. Arthritis and Rheumatism, 14, 41-54.

Castor, C. W., and Muirden, K. D. (1964). Collagen formation in monolayer cultures of human fibroblasts. The effects of hydrocortisone. Laboratory Investigation, 13, 560-574.

Castor, C. W., Ritchie, J. C., Smith, S. F., Scott, M. E., and Harnsberger, S. C. (1974). Connective tissue activation. VI. The effects of cyclic nucleotides on human synovial cells in vitro. Journal of Laboratory and Clinical Medicine, 84, 46-55.

Clarris, B. J., and Fraser, J. R. E. (1967). The effects of homologous and heterologous whole serum upon multiplication of recently-isolated human synovial cells in culture. Australian Journal of Experimental Biology and Medical Science, 45, 549-560.

Clarris, B. J., and Fraser, J. R. E. (1968). On the pericellular zone of some mammalian cells in vitro. Experimental Cell Research, 49, 181-193.

Clarris, B. J., Fraser, J. R. E., Baxter, E., and Malcolm, L. P. (In press). Effects of carrageenin on human synovial cells in vitro: morphology, growth, hyaluronic acid production and the lysosomal system. Annals of the Rheumatic Diseases.

Cohn, Z. A., and Parks, E. (1967). The regulation of pinocytosis in mouse macrophages. III. The induction of vesicle formation by nucleosides and nucleotides. Journal of Experimental Medicine, 125, 457-473.

Dayer, J.-M., Krane, S. M., Russell, R. G. G., and Robinson, D. R. (1976). Production of collagenase and prostaglandins by isolated adherent rheumatoid synovial cells. Proceedings of the National Academy of Sciences of the USA;73, 945949.

Fraser, J. R. E., and Clarris, B. J. (1978). In Research into Rheumatoid Arthritis and Allied Diseases. Edited by D. C. Dumonde and R. N. Maini. MTP: Press Lancaster.

Fraser, J. R. E., and McCall, J. R. (1965). Culture of synovial cells in vitro. Annals of the Rheumatic Diseases, 24, 351-359.

Granner, D. K., Sellers, L., Lee, A., Butters, C., and Kutina, L. (1975). A comparison of the uptake, metabolism, and action of cyclic adenine nucleotides in cultured hepatoma cells. Archives of Biochemistry and Biophysics, 169, 601615.

Henion, W. F., Sutherland, E. W., and Posternak, Th. (1967). Effects of derivatives of adenosine $3^{\prime}, 5^{\prime}$-phosphate on liver slices and intact animals. Biochimica et Biophysica Acta, 148, 106-113.

Hsie, A. W., Kawashima, K., O'Neill, J. P., and Schröder, C. H. (1975). Possible role of adenosine cyclic $3^{\prime}: 5^{\prime}$. monophosphate phosphodiesterase in the morphological transformation of Chinese hamster ovary cells mediated by $\mathrm{N}^{6}, \mathrm{O}^{2 \prime}$-dibutyryl adenosine cyclic $3^{\prime}, 5^{\prime}$-monophosphate. Journal of Biological Chemistry, 250, 984-989.

Jacobs, J. P., Jones, C. M., and Baille, J. P. (1970). Characteristics of a human diploid cell designated MRC-5. Nature, 227, 168-170.

Johnston, G. S., and Pastan, I. (1972). Role of $3^{\prime}, 5^{\prime}$-adenosine monophosphate in regulation of morphology and growth of transformed and normal fibroblasts. Journal of the National Cancer Institute, 48, 1377-1387.

Kaplan, A., Achord, D. T., and Sly, W. S. (1977). Phos phohexosyl components of a lysosomal enzyme are reco nised by pinocytosis receptors on human fibroblast Proceedings of the National Academy of Sciences, of the USA, 74, 2026-2030.

Kinsella, T. D., Baum, J., and Ziff, M. (1970). Studies ơ isolated synovial lining cells of rheumatoid and norf rheumatoid synovial membranes. Arthritis and Rheumatism. 13, 734-753.

Le Marshall, J., Fraser, J. R. E., and Muirden, K. D. (1977). Lysosomal activation by neutral saccharides in ce $\vec{b}$ cultures of synovium. Annals of the Rheumatic Diseases 36, 130-138.

Miller, S. S., Wolf, A. M., and Arnaud, C. D. (1976). Bon? cells in culture: morphologic transformation by hormone Science, 192, 1340-1343.

Muirden, K., Fraser, J. R. E, and Clarris, B. (1967). Ferritid formation by synovial cells exposed to haemoglobin i⿱口龰 vitro. Annals of the Rheumatic Diseases, 26, 251-259.

Neufeld, E. F., Sando, G. N., Garvin, A. J., and Rome, L. F. (1977). In press. As quoted by Neufeld, E., in Upsalä Journal of Medical Science, 82.

O'Keefe, E., and Cuatrecases, P. (1974). Cholera toxi mimics melanocyte stimulating hormone in inducing differentiation in melanoma cells. Proceedings of the National Academy of Sciences of the USA 71, 2500-25040

Ortiz, J. R., Yamada, T., and Hsie, A. W. (1973). Induction of the stellate configuration in cultured iris epithelial cells by adenosine and compounds related to adenosine $3^{\prime}: 5$ cyclic monophosphate. Proceedings of the National Academ of Sciences of the USA, 70, 2286-2290.

Severson, A. R., Rothberg, P. F., Pratt, R. M. and Goggin J. F. (1973). Effect of parathyroid hormone on the in corporation of ${ }^{3} \mathrm{H}$-glucosamine into hyaluronic acid i $\overrightarrow{\mathrm{B}}$ bone organ culture. Endocrinology, 92, 1282-1285.

Werb, Z., and Burleigh, M. C. (1974). A specific collagenase from rabbit fibroblasts in monolayer culture. Biochemistr Journal, 137, 373-385.

Werb, Z., Mainardi, C. L., Vater, C. A., and Harris, E. Div (1977). Endogenous activation of latent collagenase b. rheumatoid synovial cells. New England Journal of Medie cine, 296, 1017-1023.

Werb, Z., and Reynolds, J. J. (1974). Stimulation by endö cytosis of the secretion of collagenase and neutral pros teinase from rabbit synovial fibroblasts. Journal of Experi

mental Medicine, 140, 1482-1497.
Williamson, N., James, K., Ling, N. R., and Holt, L. $P_{\triangle}^{\text {J }}$ (1966). Synovial cells. A study of the morphology and aw examination of protein synthesis of synovial cells. Annals of the Rheumatic Diseases, 25, 534-546.

Willingham, M. C., and Pastan, I. (1975). Cyclic AMP and cell morphology in cultured fibroblasts. Journal of Cets Biology, 67, 146-159.

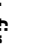

